\title{
Relationship between Obesity, Serum Uric Acid, Serum Potassium and Glomerular Filtration Rate with Electric Left Ventricular Hypertrophy in Blacks Central Africans with High Blood Pressure
}

\author{
Bertrand Fikahem Ellenga Mbolla1*, Paul Macaire Ossou Nguiet1, Richard Loumingou1, \\ Meo Stéphane Ikama1 ${ }^{1}$, Narcisse Ngangoue ${ }^{2}$, Thierry Raoul Gombet ${ }^{1}$, Henri Germain Monabeka ${ }^{1}$, \\ Benjamn Longo Mbenza ${ }^{3}$, Gisèle Kimbally Kaky ${ }^{1}$
}

${ }^{1}$ Department of Doctoral Studies, Faculty of Health Sciences, Marien Ngouabi University of Brazzaville, Brazzaville, Congo

${ }^{2}$ Laboratoire de biochimie CHU de Brazzaville, Brazzaville, Congo

${ }^{3}$ Faculty of Health Sciences, Walter Sisulu University, Queenstown, Eastern Cape, South Africa

Email: ^fikabertrand@yahoo.fr

How to cite this paper: Ellenga Mbolla, B.F., Ossou Nguiet, P.M., Loumingou, R., Ikama, M.S., Ngangoue, N., Gombet, T.R., Monabeka, H.G., Longo Mbenza, B. and Kimbally Kaky, G. (2018) Relationship between Obesity, Serum Uric Acid, Serum Potassium and Glomerular Filtration Rate with Electric Left Ventricular Hypertrophy in Blacks Central Africans with High Blood Pressure. World Journal of Cardiovascular Diseases, 8, 248-255. https://doi.org/10.4236/wjcd.2018.84024

Received: April 5, 2018

Accepted: April 27, 2018

Published: April 30, 2018

Copyright $\odot 2018$ by authors and Scientific Research Publishing Inc. This work is licensed under the Creative Commons Attribution International License (CC BY 4.0).

http://creativecommons.org/licenses/by/4.0/ (c) (i) Open Access

\begin{abstract}
The authors conducted a retrospective study over a period of 6 months in a hypertensive population in order to determine the correlation between serum uric acid on glomerular filtration rate (GFR) and estimated serum potassium with left ventricular hypertrophy (LVH) and obesity. This study enrolled 122 patients including 63 women (51.6\%). The mean age was $55.9 \pm 10.6$ years (range 30 to 74 years). Obesity weight was found in 38 cases $(31.1 \%)$ of which 20 were men (33.9\%) and 18 women (28.6\%). Abdominal obesity was found in 104 cases $(85.2 \%)$. The average serum uric acid in patients with obesity weight was $63.3 \pm 18.9 \mathrm{mg} / \mathrm{L}$ vs $62.4 \pm 14.2 \mathrm{mg} / \mathrm{L}$ for no-obese patients $(p=$ $0.63)$. The average serum potassium in obese patients was $4.06 \pm 0.42 \mathrm{mEq} / \mathrm{L}$ vs $4.02 \pm 0.46 \mathrm{mEq} / \mathrm{L}$ for no-obese $(p=0.65)$. The average GFR was $73.4 \pm$ $21.4 \mathrm{ml} / \mathrm{L}$ in obese patients vs $66.6 \pm 22.6 \mathrm{ml} / \mathrm{min}$ in no-obese $(p=0.03)$. The LVH was found in 81 cases (66.4\%). The LVH was found in 65 (62.5\%) obese patients vs $16(88 \%)$ non-obese patients $(\mathrm{OR}=4.8,95 \% 1.04-22 p=0.02)$. Only abdominal obesity has been correlated with left ventricular hypertrophy after multivariate analysis. Emphasis must be focused on public health actions for effective and appropriate measures against obesity and hypertension, whose prevalence is increasing in our region.
\end{abstract}




\section{Keywords}

Obesity, High Blood Pressure, Glomerular Filtration Rate, Uric Acid, Serum Potassium, Black African

\section{Introduction}

The management of high blood pressure (HBP) and other cardiovascular risk factors remains problematic in sub-Saharan Africa. Indeed, because of poverty, achieving minimum balance required to identify factors associated with HBP remains uncertain because of low socio-economic development. The correlation of obesity with dyslipidemia or diabetes has been established by several authors [1] [2] [3] [4]. The serum uric acid, independent cardiovascular risk factor, remains little tested in our environment [5]. The prevalence of kidney disease evaluated by estimated glomerular filtration rate (GFR) is increasing in rural Africa [6]. The left ventricular hypertrophy (LVH) represents the anomaly found in most of the electrocardiogram in HBP patients and is often correlated with other cardiovascular risk factors [7]. Hitherto, no study has been conducted in Brazzaville to assess the relationship of various cardiovascular risk factors with LVH in patients with HBP.

This study was conducted to establish the correlation between serum uric acid, serum potassium and GFR with electrical LVH and obesity in Congolese patients with HBP.

\section{Patients and Method}

This cross sectionnal study was conducted from April to September 2014 (6 months) in the outpatient unit of University Hospital of Brazzaville.

We are included the patients with HBP in initial consultation, with no current antihypertensive treatment, followed as an outpatient and whose records included the following variables: age, sex, weight $(\mathrm{cm})$, height $(\mathrm{m})$, waist circumference $(\mathrm{cm})$, medical history of cardiovascular risk factor and disease, The diet blood biochemistry analysis (uric acid, creatinine, serum potassium) are effectuate in the laboratory of biochemistry of Teaching Hospital of Brazzaville. The automaton HORIBA@ has been used. The electrocardiogram (EKG) have been realised with SCHILLER@ device.

Patients treated with gout or allopurinol were excluded from the study as well as those who had in the history impaired renal function or aged 75 and older. Ethical issues were taken into account according to the Helsinki Declaration.

The following variables were analyzed: age, sex, obesity, underweight and overweight across the body mass index (BMI), abdominal obesity, uric acid in $\mathrm{mg} / \mathrm{L}$, serum creatinine in $\mathrm{mg} / \mathrm{L}$, GFR in $\mathrm{ml} / \mathrm{min}$, the serum potassium in $\mathrm{mEq} / \mathrm{L}$ and LVH.

BMI was calculated manually by the formula weight (in kilograms) on the square of height (in meters), weight obesity was defined as BMI greater than 30 , 
overweight was defined as BMI between 25 and 29.9. Abdominal obesity was defined as waist circumference (PA) measured with a tape $-\mathrm{m} \geq 94 \mathrm{~cm}$ for men and $80 \mathrm{~cm}$ for women based on the International Diabetes Foundation criteria (IDF) [8]. The GFR was calculated manually by the formula Crockcroft-Gault $(\mathrm{mL} / \mathrm{min})$ is $(140-$ age in years $) \times$ weight in kilograms/7.2 $\times$ blood levels of creatinine in $\mathrm{mg} / \mathrm{l}$ (for women the result is multiplied by 0.85 ) [9]; positivity criteria of LVH were the Sokolow-Lyon (S amplitude in V1 plus R amplitude in V5 or V6) and Cornell ( $\mathrm{R}$ amplitude in aVL plus S amplitude in V3) [7]. We found that $\mathrm{LVH}$ was present if the Sokolow was $\geq 3.5 \mathrm{mV}$ or Cornell index $\geq 2 \mathrm{mV}$ in men and $\geq 2.8 \mathrm{mV}$ in women.

Serum creatinine, uric acid and potassium were performed at the biochemistry laboratory of the CHU of Brazzaville with an automaton PLC Lysa ${ }^{\circledR} 500$. ECGs were conducted with a Schiller AT- ${ }^{\circledR}$ device.

The variables have been analyzed by the software Epi Info 3.3.2 of CDC (Atlanta, USA). The qualitative variables were expressed as number and percentage, quantitative variables as mean \pm standard deviation and extremes. The univariate analysis had use, the calculation of Odds ratio (OR) with confidence interval (CI) of 95\%. A logistic regression model of LVH was used for multivariate analysis adjusting for independent variables. The significance level of the comparisons was less than $5 \%$.

\section{Results}

This study included 122 patients, 63 women (51.6\%). The population characteristics are reported in Table 1.

Table 1. Characteristics of the study population.

\begin{tabular}{|c|c|c|c|c|}
\hline & $\begin{array}{c}\text { All } \\
(\mathrm{n}=122)\end{array}$ & $\begin{array}{c}\text { Men } \\
(\mathrm{n}=59)\end{array}$ & $\begin{array}{l}\text { Women } \\
(\mathrm{n}=63)\end{array}$ & $p$ value \\
\hline Mean age ${ }^{*}($ years $)$ & $55.9 \pm 10.6$ & $56.2 \pm 10.6$ & $55.7 \pm 10.8$ & NS \\
\hline \multicolumn{5}{|l|}{ Parameters of obesity } \\
\hline Mean $\mathrm{BMI}^{*}$ & $28.1 \pm 3.3$ & $28.3 \pm 3.3$ & $27.9 \pm 3.2$ & NS \\
\hline Weight obesity & $38(31.1 \%)$ & $20(33.9 \%)$ & $18(28.6 \%)$ & NS \\
\hline Overweight & $70(57.3 \%)$ & $31(52.5 \%)$ & $39(61.9 \%)$ & \\
\hline Waist obesity & $104(85.2 \%)$ & $44(74.6 \%)$ & $60(95.2 \%)$ & 0.001 \\
\hline Waist circumference $(\mathrm{cm})^{*}$ & $94.1 \pm 8$ & $96.9 \pm 6.8$ & $91.4 \pm 8.1$ & $<0.001$ \\
\hline \multicolumn{5}{|l|}{ Medical history } \\
\hline No medical history & $42(34.4 \%)$ & $22(37.3 \%)$ & $20(31.8 \%)$ & NS \\
\hline No CVD** & $61(50 \%)$ & $32(50.8 \%)$ & $29(49.2 \%)$ & NS \\
\hline \multicolumn{5}{|l|}{ Blood biochemia } \\
\hline Serum creatinine $e^{\star}(\mathrm{mg} / \mathrm{l})$ & $13.21 \pm 3.23$ & $14.1 \pm 3.5$ & $12.4 \pm 2.7$ & 0.01 \\
\hline Kalemia* $\left.^{*} \mathrm{mEq} / \mathrm{l}\right)$ & $4 \pm 0.45$ & $4 \pm 0.52$ & $4 \pm 0.37$ & NS \\
\hline Serum uric $\operatorname{acid}^{\star}(\mathrm{mg} / \mathrm{l})$ & $63.35 \pm 15.7$ & & & 0.01 \\
\hline
\end{tabular}

*variables range: Age: 30 and 74; serum creatinine 6 and 26; BMI (Body mass index) 22 and 36; waist circumference 75 and 122; kalemia 3.1 and 5.7; serum uric acid 40 and 128; GFR (Glomerular filtration rate) 23 and $122 .{ }^{* *} \mathrm{CVD}$ : cardiovascular disease, NS: no significant. 


\subsection{Obesity Weight}

Obesity weight was found in 38 cases (31.1\%), divided into 20 men (33.9\%) and 18 women $(28.6 \%)$ [OR $=0.78,95 \%$ CI $0.36-1.68, p=0.33]$. The average serum uric acid was $63.3 \pm 18.9 \mathrm{mg} / \mathrm{L}$ for patients with obesity underweight, and $62.4 \pm$ $14.2 \mathrm{mg} / \mathrm{L}$ for non-obese patients $(p=0.63)$. The uric acid was normal in $19 \mathrm{ob}-$ ese patients $(37.3 \%)$ and high in 19 obese patients $(26.8 \%)$ whereas in non-obese, it was normal in 32 cases $(62.7 \%)$ and high in 52 cases $(73.2 \%)$ [OR $=1.6,95 \%$ CI $0.74-3.52, p=0.15]$. Among the obese patients, the average serum potassium was $4.06 \pm 0.42 \mathrm{mEq} / \mathrm{L}$, and for non-obese $4.02 \pm 0.46 \mathrm{mEq} / \mathrm{L}(p=0.65)$.

The average serum creatinine was $13.91 \pm 2.9 \mathrm{ml} / \mathrm{L}$ for obese, and $12.9 \pm 3.3$ $\mathrm{ml} / \mathrm{L}$ for non-obese $(p=0.13)$. The average GFR was $73.4 \pm 21.4 \mathrm{ml} / \mathrm{min}$ for obese and $66.6 \pm 22.6 \mathrm{ml} / \mathrm{min}$ for non-obese patients $(p=0.03)$. The LVH was determinate in 24 obese patients $(63.2 \%)$ and in 54 non-obese patients $(67.9 \%)$ [OR $=0.81,95 \%$ CI $0.36-1.81, p=0.37]$.

\subsection{Abdominal Obesity}

Abdominal obesity was found in 104 cases (85.2\%), 44 men (74.6\%) and 60 women $(95.2 \%)$ [OR $=7.14,95 \%$ CI $1.8-25, p=0.001]$. The average serum uric acid was $63.8 \pm 16.1 \mathrm{mg} / \mathrm{L}$ in non-obese, and $62.8 \pm 15.7 \mathrm{mg} / \mathrm{L}$ in the obese $(p=$ $0.80)$. The serum potassium was on average $4 \pm 0.64 \mathrm{mEq} / \mathrm{L}$ for non-obese patients and $4.04 \pm 0.41 \mathrm{mEq} / \mathrm{L}$ for obese patients $(p=0.20)$. The average serum creatinine was $13 \pm 2.95 \mathrm{mg} / \mathrm{L}$ for obese patients and $14.57 \pm 4.56$ for non-obese patients $(p=0.28)$. The average GFR was $55 \pm 15.7 \mathrm{ml} / \mathrm{min}$ for non-obese patients, and $71.1 \pm 22.5 \mathrm{ml} / \mathrm{min}$ for the obese $(p=0.007)$.

The LVH was found in 65 obese patients (62.5\%) and in 16 non-obese patients (88\%). The LVH was absent in two non-obese patients $(11.1 \%)$ and in 39 obese patients $(37.5 \%)$ [OR $=4.8,95 \%$ CI 1.04 to $22, p=0.02]$.

\subsection{LVH}

The LVH was found in 81 cases (66.4\%). There were 42 men (51.9\%) and 39 women $(48.1 \%)$. The average serum creatinine was $12.92 \pm 3.44 \mathrm{mg} / \mathrm{L}$ for patients with $\mathrm{LVH}$ and $2.72 \pm 13.78 \mathrm{mg} / \mathrm{L}$ for patients without LVH $(p=0.11)$. The average serum potassium was $4 \pm 0.46 \mathrm{mEq} / \mathrm{L}$ for patients with $\mathrm{LVH}$, and $4 \pm$ $0.41 \mathrm{mEq} / \mathrm{L}$ for patients without LVH $(p=0.60)$. The average serum uric acid was $64.6 \pm 16.3 \mathrm{mg} / \mathrm{L}$ for patients with $\mathrm{LVH}$, and $60.8 \pm 14.1 \mathrm{mg} / \mathrm{L}$ for patients without LVH $(p=0.21)$. The DFG has averaged $70.8 \pm 23.1 \mathrm{ml} / \mathrm{min}$ for patients with $\mathrm{LVH}$, and $64.6 \pm 20.5 \mathrm{ml} / \mathrm{min}$ for patients without LVH $(p=0.15)$.

The multivariate analysis between LVH and different parameters is given in Table 2 .

\section{Discussion}

The change in lifestyle and eating habits has led to an increase in the prevalence of obesity and hypertension in sub-Saharan Africa [1] [2]. The prevalence of 
Table 2. Multivariate analysis between left ventricular hypertrophy and other parameters.

\begin{tabular}{ccccc}
\hline & Odds Ratio & IC 95\% & Z-Statistic & $p$ value \\
\hline GFR & 1.0199 & $1.000-1.0402$ & 1.9577 & 0.0503 \\
Kalemia & 0.9904 & $0.9014-1.0881$ & -0.2008 & 0.8409 \\
Obesity & 0.9528 & $0.4058-2.2375$ & -0.1109 & 0.9117 \\
Waist obesity & $\mathbf{0 . 1 5 6 1}$ & $\mathbf{0 . 0 3 1 8 - 0 . 7 6 6 5}$ & -2.2876 & $\mathbf{0 . 0 2 2 2}$ \\
Serum uric acid & 1.0146 & $0.9877-1.0421$ & 1.0577 & 0.2902 \\
Constant & - & - & 0.222 & 0.8243 \\
\hline
\end{tabular}

${ }^{*}$ GFR: glomerular filtration rate.

abdominal obesity in this study (85.2\%) is higher than the weight of obesity (31.1\%), the first is predominant among women and second among men.

In sub-Saharan Africa, the prevalence of obesity and hypertension weight varies by region [3], and appear lower than that found in populations of the black diaspora. In fact, they remain subject to the same constraints as other populations of Western society.

Abdominal obesity, which represents a risk factor in the metabolic syndrome [9] [10], is very high in our study population. The metabolic syndrome is increasing substantially in different cities in sub-Saharan Africa with a corollary to increased cardiovascular risk [11].

Different studies have not established a clear correlation between obesity and hypertension except in South Africa [3], but obesity is a predictor of hypertension especially in female subjects [12].

The increasing prevalence of obesity being related to the Westernization of lifestyle in Africa, it also denotes a larger increase in disadvantaged populations, this seems related to low education and job insecurity [2] [13].

The GFR was higher in obese patients than in non-obese patients in our series. This is linked to glomerular hyperfiltration physiological linked to overweight [9]. Obesity does not appear to be correlated with serum uric acid, or potassium, or the GFR in our series. According to the literature, uric acid seems rather to be correlated with increased blood glucose and the installation of type 2 diabetes [14] [15]. Through this indirect pathway it could intervene on the emergence/appearance of obesity.

Hyperuricemia is considered an independent risk factor, it plays a pathological role in the progression of hypertension and impaired renal function [16]. Drug treatment of hyperuricemia allows better control of hypertension and renal function, but also would reduce the cardiovascular risk [17] [18]. These observations are unreliable, and large-scale studies are needed to confirm these observations [15] [16] [19].

The change in lifestyle of people has increased the prevalence of renal failure [4] [6] [20] [21], obesity [2] [3] in addition to hypertension and diabetes [3].

Among the factors analyzed in study notes, only abdominal obesity seems positively correlated with LVH. Indeed, among the factors induced by obesity in 
hypertensive patients, LVH is revealed most strongly correlated according to Norton, in a series in South Africa [22]. Among the factors analyzed, only the GFR would be implicated in the occurrence of LVH [23] [24] [25]. It is also recognized that the decrease in GFR increase cardiovascular mortality [26]. LVH is negatively correlated with abdominal obesity, but not with obesity. In his series, Son et al found positive correlation with abdominal obesity and obesity. The difference may be methodological, because of the high number of patients included in his study [27].

\section{Conclusion}

It appears that among the various parameters analyzed, only abdominal obesity is correlated with LVH. Given the change in lifestyle now westernized in African cities, the emphasis must be placed on public health actions for public awareness for effective preventive and control measures against obesity and HBP.

\section{References}

[1] Doll, S., Paccaud, F., Bovet, P., Burmer, M. and Wietlisbach, V. (2002) Body Mass Index, Abdominal Adipocity and Blood Pressure: Consistency of Their Association across Developing and Developed Countries. International Journal of Obesity, 26, 48-57. https://doi.org/10.1038/sj.ijo.0801854

[2] Sodjinou, R., Agueh, V., Fayomi, B. and Delisle, H. (2008) Obesity and Cardio-Metabolic Risk Factors in Urban Adults of Benin: Relationship with Socio-Economic Status, Urbanisation, and Lifestyle Patterns. BMC Public Health, 4, 84. https://doi.org/10.1186/1471-2458-8-84

[3] Cappuccio, F.P., Kerry, S.M., Adeyemo, A., Luke, A., Amoah, A.G., Bovet, P., et al. (2008) Body Size and Bloob Pressure: An Analysis of Africans and the African Diaspora. Epidemiology, 19, 38-46. https://doi.org/10.1097/EDE.0b013e31815c4d2c

[4] Longo-Mbenza, B., Ngoma, D.V., Nahimana, D., Mayuku, D.M., Fuele, S.M., Ekwanzala, F., et al. (2008) Screen Detection and the WHO Stepwise Approach to the Prevalence and Risk Factors of Arterial Hypertension in Kinshasa. European Journal of Cardiovascular Preventive Rehabilitation, 15, 503-508. https://doi.org/10.1097/HJR.0b013e3282f21640

[5] Longo-Mbenza, B., Luila, E.L., Mbete, P. and Vita, E.K. (1999) Is Hyperuricemia a Risk Factor of Stroke and Coronary Heart Disease among Africans? International Journal of Cardiology, 71, 17-22. https://doi.org/10.1016/S0167-5273(99)00097-2

[6] Sumaili, E.K., Krzesinski, J.M., Zinga, C.V., Cohen, E.P., Delanaye, P., Munyanga, S.M., et al. (2009) Prevalence of Chronic Kidney Disease in Kinshasa: Results of a Pilot Study from the Democratic Republic of Congo. Nephrology Dialysisand Transplantation, 24, 117-122. https://doi.org/10.1093/ndt/gfn469

[7] Gosse, P., Papaioannou, G., Dubiez, P., Reuter, S. and Lemetayer, P. (2008) Hypertrophie ventriculaire gauche au cours de l'hypertension artérielle. EMC (Elsevier Masson SAS, Paris), Cardiologie, 11-301-I-10.

[8] The IDF Consensus Worldwide Definition of the Metabolic Syndrome (2014). https://www.idf.org/e-library/consensus-statements/60-idfconsensus-worldwide-def initionof-the-metabolic-syndrome

[9] Charriere, S., Rognant, N., Chiche, F., Cremer, A., Deray, G. and Priou, M. (2009) 
Chronic Renal Insufficiency and Cardiovascular Disease. Annalesde Cardiologieet Angeiologie, 58, 40-52. https://doi.org/10.1016/j.ancard.2008.07.010

[10] Eckel, R.H. and Zimmet, P.Z. (2005) The Metabolic Syndrome. Lancet, 365, 1415-1428. https://doi.org/10.1016/S0140-6736(05)66378-7

[11] Kelliny, C., William, J., Riesen, W., Paccaud, F. and Bovet, P. (2008) Metabolic Syndrome According to Different Definitions in a Rapidly Developing Country of the Africa Region. Cardiovascular Diabetology, 7, 27.

[12] Shuger, S.L., Sui, X., Church, T.S., Meriwether, R.A. and Blair, S.N. (2008) Body Mass Index as a Predictor of Hypertension Incidence among Initially Healthy Normotensive Women. American Journal of Hypertension, 21, 613-619. https://doi.org/10.1038/ajh.2008.169

[13] Ziraba, A.K., Fotso, J.C. and Ochako, R. (2009) Overweight and Obesity in Urban Africa: A Problem of the Rich or the Poor? BMC Public Health, 9, 465. https://doi.org/10.1186/1471-2458-9-465

[14] Choi, H.K., De Vera, M.A. and Krishnan, E. (2008) Gout and the Risk of Type 2 Diabetes among Men with a High Cardiovascular Risk Profile. Rheumatology, 47, 1567-1570. https://doi.org/10.1093/rheumatology/ken305

[15] Dehghan, A., Van Hoek, M., Sijbrands, E.J., Hofman, A. and Witterman, J.C. (2008) High Serum Acid as a Novel Risk Factor for Type 2 Diabetes. Diabetes Care, 31, 361-362. https://doi.org/10.2337/dc07-1276

[16] Ohno, I. and Hosoya, T. (2008) Measures against Hyperuricemia. Nihon Rinsho, 66, 1779-1785.

[17] Stewart, G.A., Gansevoort, R.T., Mark, P.B., Rooney, E., Mcdonagh, T.A., Dargie, H.J., et al. (2005) Electrocardiographic Abnormalites and Uremic Cardiomyopathy. Kidney International, 67, 217-226.

[18] Leoncini, G., Viazzi, F., Parodi, D., Ratto, E., Vettoretti, S., Vaccaro, V., Ravera, M., et al. (2004) Creatinine Clearance and Signs of End-Organ Damage in Primary Hypertension. Journal of Human Hypertension, 18, 511-516. https://doi.org/10.1038/sj.jhh.1001689

[19] Alderman, M. and Redferm, J.S. (2004) Serum Uric Acid-A Cardiovascular Risk Factor? Therapeutische Umschau, 61, 547-552. https://doi.org/10.1024/0040-5930.61.9.547

[20] Conen, D., Wietlisbach, V., Bovet, P., Shamlaye, C., Riesen, W., Paccaud, F. and Burnier, M. (2004) Prevalence of Hyperuricemia and Relation of Serum Uric Acid with Cardiovascular Risk Factors in a Developing Country. BMC Public Health, 4, 9. https://doi.org/10.1186/1471-2458-4-9

[21] Weaver, A.L. (2008) Epidemiology of Gout. Clevel and Clinic Journal of Medicine, 75, S9-S12.

[22] Njelekela, M.A., Mpembeni, R., Muhihi, A., Mligiliche, N.L., Spiegelman, D., Hertzmark, E., et al. (2009) Gender-Related Differences in the Prevalence of Cardiovascular Disease Risk Factors and Their Correlates in Urban Tanzania. BMC Cardiovascular Disorders, 9, 30. https://doi.org/10.1186/1471-2261-9-30

[23] Sumaili, E.K., Nseka, N.M., Lepira, F.P., Krzesinski, J.M., Makulo, J.R., Bukabau, J.B., et al. (2008) Screening for Proteinuria and Chronic Kidney Disease Risk Factors in Kinshasa: A World Kidney Day 2007 Study. Nephron Clinical Practice, 110, c220-c228. https://doi.org/10.1159/000167869

[24] Norton, G.R., Majane, O.H., Libhaber, E., Maseko, M.J., Makaula, S. and Woodwiss, A.J. (2009) The Relationship between Blood Pressure and Left Ventricular Mass In- 
dex Depends on an Exces Adiposity. Journal of Hypertension, 27, 1873-1883.

[25] Ulasi, I.I., Arodiwe, E.B. and Ijoma, C.K. (2006) Left Ventricular Hypertrophy in African Black Patients with Chronic Renal Failure at First Evaluation. Ethnicity and Disease, 16, 859-864.

[26] Hou, F.F., Ma, Z.G., Mei, C.L., Rong, S., Huang, S.M., Liu, X.R., Yuan, W.J., et al. (2005) Cardiovascular Disease in Chinese Chronic Renal Insufficiency Patients-Epidemiology Survey. National Medical Journal of China, 85, 458-63.

[27] Son, J.-W., Sung, J.K., Lee, J.-W., Youn, Y.J., Ahn, M.-S., Ahn, S.G., et al. (2016) Abdominal Obesity and Structure and Function of the Heart in Healthy Male Koreans. The ARIRANG Study. Medicine, 95, e4930.

https://doi.org/10.1097/MD.0000000000004930 